ARTICLE

DOI: $10.1057 / s 41599-018-0096-6$

\title{
Assessing the relative contribution of economic, political and environmental factors on past conflict and the displacement of people in East Africa
}

\author{
Erin Llwyd Owain ${ }^{1} \&$ Mark Andrew Maslin (1) ${ }^{1}$
}

\begin{abstract}
According to the UN Refugee Agency in 2016 there were over 20 million displaced people in Africa. There is considerable debate whether climate change will exacerbate this situation in the future by increasing conflict and thus displacement of people. To explore this climate-conflict-refugee nexus this study analyses whether climatic changes between 1963 and 2014 impacted the risk of conflict and displacement of people in East Africa. A new composite conflict database recording major episodes of political violence (MEPV) was compared with climatic, economic and political indicators using optimisation regression modelling. This study found that climate variations as recorded by the Palmer Drought Severity Index (PDSI) and the global temperature record did not significantly impact the level of regional conflict or the number of total displaced people (TDP). The major driving forces on the level of conflict were population growth, economic growth and the relative stability of the political regimes. Numbers of TDP seemed to be linked to population and economic growth. Within TDP, 'refugees' were recorded as people that were forced to cross borders between countries. In contrast to TDP and conflict, variations in refugee numbers were found to be significantly related to climatic variations as well as political stability, population and economic growth. This study suggests that climate variations played little or no part in the causation of conflict and displacement of people in East Africa over the last 50 years. Instead, we suggest rapid population growth, low or falling economic growth and political instability during the post-colonial transition were the more important controls. Nonetheless, during this period this study does shows that severe droughts were a contributing driver of refugees crossing international borders. This study demonstrates that within socially and geo-politically fragile systems, climate change may potentially exacerbate the situation particularly with regards to enforced migration.
\end{abstract}

\footnotetext{
${ }^{1}$ Department of Geography, University College London, London WC1E 6BT, UK. Correspondence and requests for materials should be addressed to M.A.M. (email: m.maslin@ucl.ac.uk)
} 


\section{Introduction}

- he total number of displaced people fleeing conflict worldwide in 2016 reached an all-time high of 65.6 million, this is four times higher than recorded a decade earlier (UNHCR, 2017). The majority of these displaced people were fleeing the on-going conflicts in Syria, Afghanistan and Somalia. Recent work has linked the onset of the Syrian civil war to climate change via the intense three-year drought proceeding the war (Gleick, 2014). This link between climate change and conflict has been explored further (e.g., Hsiang and Burke, 2014; Hendrix and Salehyan, 2012; Raleigh and Kniveton, 2012), with one study suggesting the strongest link occurs in ethnically fractionalized countries (Schleussner et al., 2016). With long-term mean temperature changes, it has been suggested that conflict will increase by $54 \%$ across sub-Saharan Africa by 2030 (Burke et al., 2009). Specific episodes of conflict have even been labelled as 'climatedriven conflicts', with the former UN Secretary General Ban Kimoon in 2007 describing the on-going war in Darfur as one of the 'first climate wars' (Ki-moon, 2007). Further to this, there has been a marked rise in key terms used by the media including the use of 'climate refugees' and 'environmental migrants' to describe people fleeing their homes from climate-driven conflict (Climate Refugee, 2010). The aforementioned assumptions suggest a mono-causal narrative wherein conflict is driven solely by climatic changes. This political stance pre-empts academic research that concludes that there is no consensus whether or not climate change is a significant driver of conflict or migration (e.g., Gleditsch, 2012; Bernauer et al., 2012; Hsiang and Burke, 2014; Buhaug et al., 2014; Adger et al., 2014; Fisk, 2015; Burrows and Kinney, 2016).

Other studies suggest alternative environmental drivers of conflict, which include resource scarcity (e.g., Barnett and Adger, 2007), freshwater resources (Hendrix and Glaser, 2007), soil degradation (Dixon, 2009), flooding (Hauge and Ellingsen, 2001) and weather-driven agricultural and food shocks (Wischnath and Buhaug, 2014). Such studies have widely been criticised as they fail to consider other factors and multi-pathway relationships (e.g., Johnson, 2003). Other studies stress that economic and social factors such as population size (Raleigh and Hegre, 2009), population growth (Homer-Dixon, 1999), economic development (cf. Blattman and Miguel, 2010; Hegre and Sambanis, 2006; Miguel et al., 2004; Slettebak, 2012) and political regime operating in a country (cf. Payne, 1995; Sen, 1999; Collier and Hoeffler, 2004; Gleditsch et al., 2009) play a fundamental part in causing conflict. Furthermore, it has been suggested that such factors may contribute to creating a fragile system, which can be exacerbated by climate change to cause conflict (De Châtel, 2014; Buhaug, 2015).

East Africa. According to the IPCC (Boko et al., 2007; Fields et al., 2014), Africa is one of the most vulnerable continents to the impacts of climate change. East Africa is predicted to experience increased unpredictability and intensity of rainfall and an overall increase in annual average rainfall of between 5 and $50 \mathrm{~mm}$ per decade (Boko et al., 2007). Throughout East Africa, recent economic development has been concentrated in the agricultural sector which in some countries accounts for more than $50 \%$ of gross domestic product (GDP) (Boko et al., 2007); a sector which is highly climate-sensitive. It is claimed that declining rainfall in Africa during the last century, may have reduced African GDP by $15-40 \%$ compared with the rest of the developing world (Barrios et al., 2010). East Africa has a long history of conflict and geopolitical struggles which persist in some countries to this day, for examples the civil wars in Sudan and Somalia. The IPCC suggests that East Africa's situation is aggravated by the interaction of 'multiple stresses' which generate low adaptive capacity and high vulnerability to climate change (Fields et al., 2014). Conflict exacerbates this, as the poor and marginalised are neither provided basic services nor protected from conflict.

The literature exploring the climate-conflict link across East Africa is sparse relative to other regions and has come to contradictory conclusions. Of the studies that have been undertaken, some argue that drought and water insecurity are linked to increased social competition in East Africa (Meier et al., 2007; von Uexkull et al., 2016), while others have suggested that conflict increases during wetter than average periods (Adano et al., 2012), drier conditions (Detges, 2016; Fjelde and von Uexkull, 2012; von Uexkull, 2014), colder conditions (Iyigun et al., 2017), warmer conditions (O'Loughlin et al., 2012, 2014) or extreme deviations in either direction (Lecoutere et al., 2010; Raleigh and Kniveton, 2012; Ide et al., 2014). It has also been suggested that socioeconomic and political factors have a greater effect on conflict than climatic factors (Buhaug et al., 2015). To try and assess whether climatic changes have an influence on the stability of East African societies, we have focused on 10 countries within the region (Fig. 1) and have collated and analysed social, economic and climate data covering the last 51 years.

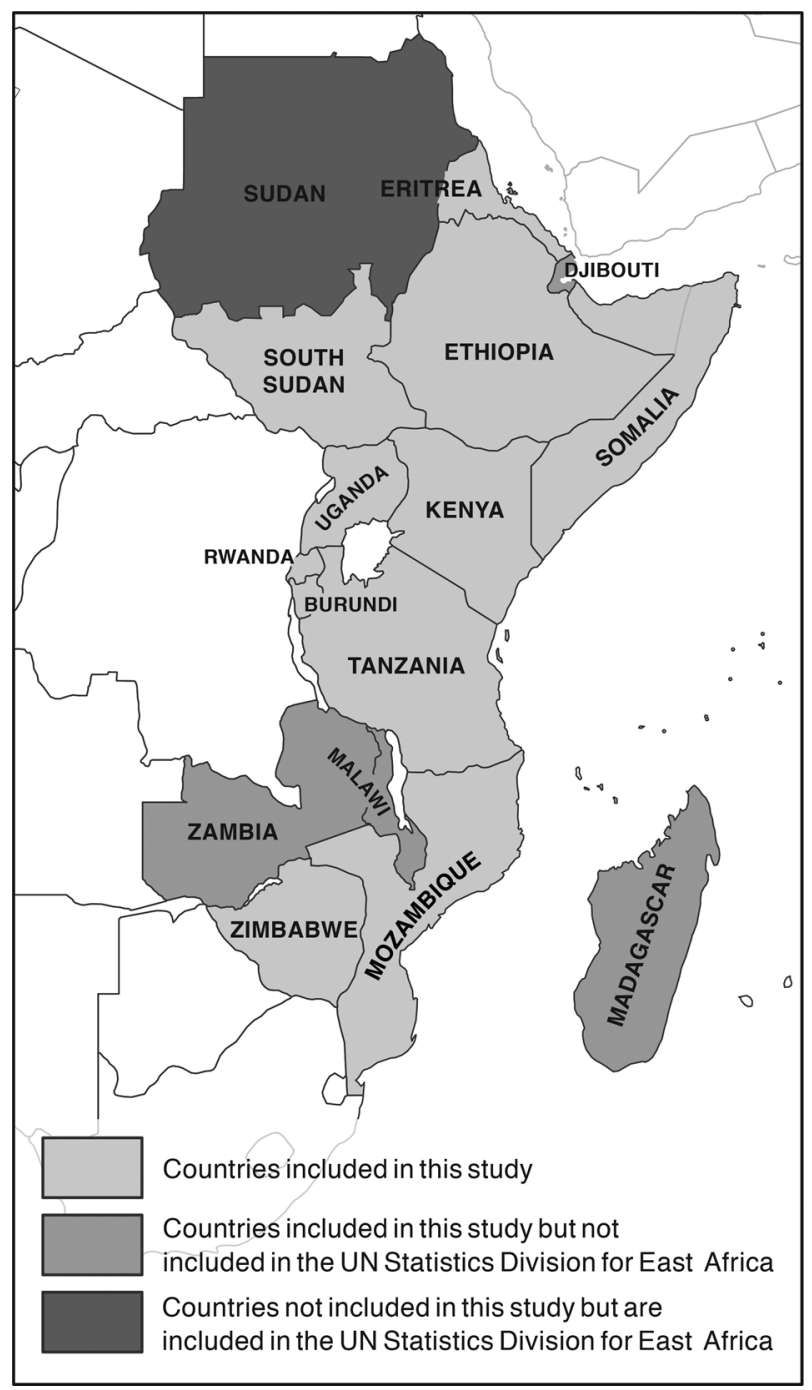

Fig. 1 Map of East Africa showing the countries that are included in this study 


\section{Methods}

Conflict data collation. Reviewing the most common conflict databases currently used within the climate-conflict research raises concerns (Eck, 2012) and this has led us to explore and use a newly developed conflict database. The UCDP/PRIO armed conflict dataset is extensively used (e.g., Sundberg et al., 2012) as its dataset has a long temporal resolution spanning 1946-2014, however, the dataset is restricted by a limited number of conflict variables and useful units limiting the use of extensive statistical analysis for more quantitative research. The Social Conflict Analysis Database (Salehyan et al., 2012) accounts for the previously stated inadequacy as it includes numerous variables of conflict, including episodes of protests, riots, and other incidences of social unrests on the basis of 'number of deaths per episode'. However, this unit of measurement exhibits significant discrepancy and uncertainty. Greater attention has recently been placed on producing databases containing georeferenced episodes of conflict such as the UCDP Georeferenced Event Database (Sundberg and Melander, 2013), however, despite the increase in spatial resolution, the database only covers the period 1989-2015 and therefore fails to capture any potential long-term climatic impact which requires at least 30 years' worth of data in order to be statistically significant. Similarly, whilst the Armed Conflict Location and Event Dataset (ACLED; Raleigh et al., 2010) enables research of local level factors, its dataset only covers a short timescale between 1997 and 2018 (but updated every month) and therefore this is a major limitation for studies concerned with decedal-scale changes. A dataset which does address this limitation and covers timescales from 1816-2007 is the Correlates of War (COW version 4.0) dataset (Sarkees and Wayman, 2010). This dataset contains an array of quantitative measurements of conflict and has been widely used within climate-conflict research. However, this dataset defines conflict with a relatively high threshold of a minimum of 1000 battle-related fatalities within a 12-month period for it to be recognised in the COW dataset. This relatively high threshold does not consider lower intensity conflict events, which probably play a significant role in smaller countries nor does it pick up multiple periods of civil disobedience and protest.

Unlike the COW dataset, a database which, to date, has not received much attention in the climate-conflict literature is the major episodes of political violence dataset (MEPV database) produced by the Centre for Systemic Peace (CSP) as part of the Integrated Network for Societal Conflict Research (Marshall, 2016a). The datasets analysed during the current study are available in the CSP repository, http://www.systemicpeace.org/ inscrdata.html. Conflict, or MEPV, can be defined as 'the systematic and sustained use of lethal political violence that result in at least 500 directly-related fatalities over the course of the episode' (Marshall, 2016b). Admittedly, unlike other datasets such as ACLED, the MEPV Dataset fails to capture small-scale, low-intensity violence, however, its advantages override this. Similar to the COW dataset, the MEPV Dataset is a recently updated global dataset which records conflict on a country-bycountry level for a long temporal resolution from 1946-2014; a key feature of the database is that this increases the possibility of detecting a climate signal. Numerous conflict variables are recorded including international violence, international war, international independence war, civil violence, civil war, ethnic violence, and ethnic war, all on an annual basis (Marshall, 2016c). Episodes are designated a 'war magnitude' which measures the societal impact using an eleven-point scale (0-10); ranging from no conflict (magnitude 0) to 'Extermination and Annihilation' (magnitude 10) (full description in Marshall, 2016b), a quantitative variable which is particularly useful for data analysis and statistical testing. A comprehensive assessment of various societal impacts including the impacts on human resources, societal networks, environmental quality, infrastructure damage and resource diversions is used to calculate the magnitude. Magnitudes are totalled to generate an overall figure on an annual basis. The main assumption of this database is that the episode location only considers those upon whose territory the political violence actually takes place therefore countries that engage in military intervention in another country are not directly affected by the violence. This study finds that the MEPV Database is a valid and reliable database since not only is all the data cross-checked with other data resources to uphold accuracy, but the 'war magnitude' index is a logistical scale which ensures that all magnitude scores across all episodes of conflict are consistent, comparable and globally uniform.

Displaced people data collation. The database used in this study to record displaced people is the Forcibly Displaced Populations Database, which is derived from the same research body as the conflict dataset; the Armed Conflict and Intervention Datasets (Marshall, 2016d). The data is compiled from the United States Committee for Refugees and Immigrants (USCRI, 2016) and the Internal Displacement Monitoring Centre (IDMC, 2016, http:// www.internal-displacement.org/globalreport2016/) and spans from 1964-2008. Data is recorded on an annual, country-level resolution, for numbers of refugees and internally displaced persons (IDP). Data is missing for years 1973, 1975 and 1979. The database is cross-checked with an extensive range of data sources including government authorities, related global databases, civil society organisations, media sources, and other sources.

Out of the twenty official East African countries according to the UN Division (Fig. 1), the conflict database records conflict for Burundi from 1962, Eritrea (1993), Ethiopia (1946), Kenya (1963), Mozambique (1975), Rwanda (1961), Somalia (1960), Sudan (1956), South Sudan (2009), Tanzania (1961), Uganda (1962), and Zimbabwe (1966). These countries represent substantial variation across climate systems, conflict experiences and political systems. For this study, since the timespan of data for Eritrea and South Sudan is relatively short, these countries are incorporated as Eritrea/Ethiopia and Sudan/South Sudan creating a total of ten countries (Fig. 1). With consideration to the time range of available data for all countries, the effects of climatic factors on the total sum of both conflict and displaced people was considered from 1963-2014 and 1964-2008, respectively for the entire region of East Africa (as a total sum of the ten countries per year) and per individual country (except Mozambique and Zimbabwe which was considered onwards from 1975 and 1966, respectively).

Climate variability data. There are many ways to measure and define climate variability (IPCC, 2013), but within the context of East Africa, effective precipitation is perceived to be the most important measurement. Many studies that explore the effects of climatic variability on conflict have used standardised precipitation index (SPI; McKee et al., 1993) as their climate index of choice (e.g., Hendrix and Salehyan, 2012). This has the drawbacks that it firstly, assumes a stationary climate, and secondly, it does not take into account other atmospheric conditions, such as temperature, which may have an equal effect on drought intensity. An alternative measure of drought or climate variability which does considers in its equations temperature and other various atmospheric conditions including wind and humidity, is the Standardised Precipitation-Evapotranspiration Index (SPEI; Vicente-Serrano et al., 2010). Despite the significant improvement to the equations against the former SPI, this drought intensity index was created as in 2010 and various papers (e.g., 
Stagge et al., 2014) which set out to test this index against the older SPI conclude that SPEI requires further rigorous testing before it is widely accepted as an improvement SPT. In the meantime we have used an alternative standardised index, the meteorological drought index called the Palmer Drought Severity Index (PDSI) which is based on a soil moisture algorithm and the water balance equation first proposed by Palmer (1965). Unlike the SPI, which requires only a single input, the PDSI index is calculated on a monthly basis using a range of inputs including precipitation, temperature and soil moisture to better represent the atmospheric conditions within the equations. The PDSI was a significant ground-breaking index when the method was first published in 1965 and even today, the method continues to uphold its reputation and continues to be widely used within the field of climate research (e.g., Heim, 2017; Cong et al., 2017; Wambua et al., 2017). Unlike the SPEI which is a relatively new method on the platform of climate research, the PDSI is a reliable, well researched method. The PSDI generates a standardised index, which ranges from $<-4$ (extreme drought) to $>+4$ (extremely wet). PSDI is suitable for this study since primarily, it allows the role of climate change to be explored by providing a measurement of climatic variability away from the normal conditions. Secondly, it is a standardised index, which allows for comparison between locations and years therefore providing an opportunity to place current conditions in a historical perspective. Finally, it incorporates aspects of the climate of the past month and therefore does not assume a stationary climate since it provides a spatial and temporal representation of the climate thus better representing the conditions on the ground (Alley, 1984). Data for the PDSI of the region of East Africa was derived from the website KNMI Climate Explorer (KNMI, 2016) using the selfcalibrated, monthly observation dataset UCAR Palmer Drought Severity Index 1850-2014 (Dai et al., 2004) which was recently updated to encompass data for the year 2014. The average for the entire region of East Africa was taken.

We also included an index to represent global climate change; the global land temperature (degrees Celsius) presented as an anomaly from the average 1970-2000 and derived from the Surface Temperature Database from Goddard Institute for Space Studies (NASA, 2016).

Socio-economic and political variables. This study includes an analysis of six other variables that have been shown in other studies to influence conflict and migration. (1) Population size, as research suggests that larger populations can be associated with an increase in conflict (Fearon and Laitin, 2003). (2) Population growth (annual rate of change in \%) as it has been suggested that rapid population growth could be associated with higher levels of conflict (Urdal, 2008). Population data are derived from the United Nations Population Division 1950-2015 (UNDP, 2017) for both sexes as a unit of thousand for each country between
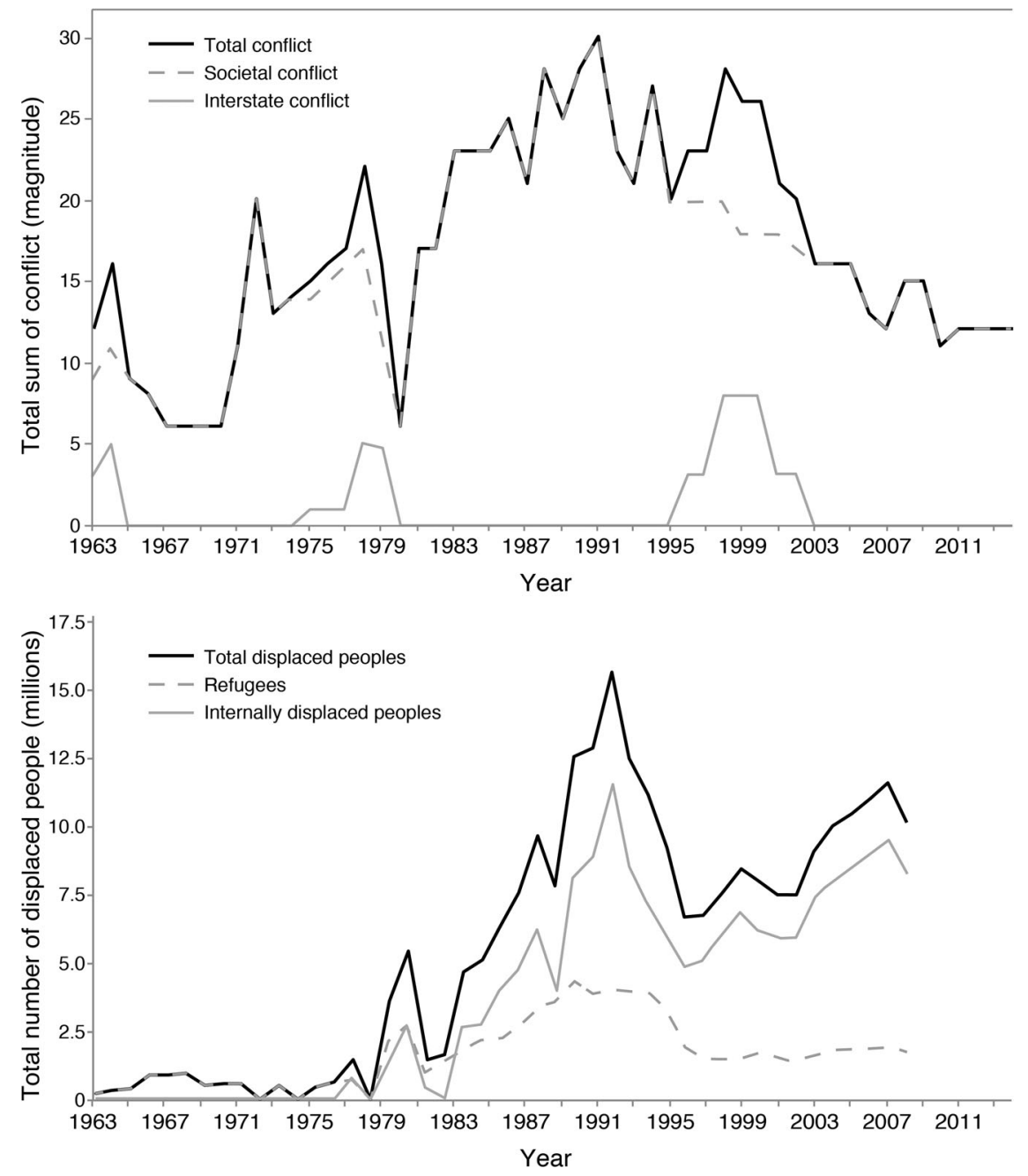

Fig. 2 Conflict and displaced people data from East Africa since 1963 

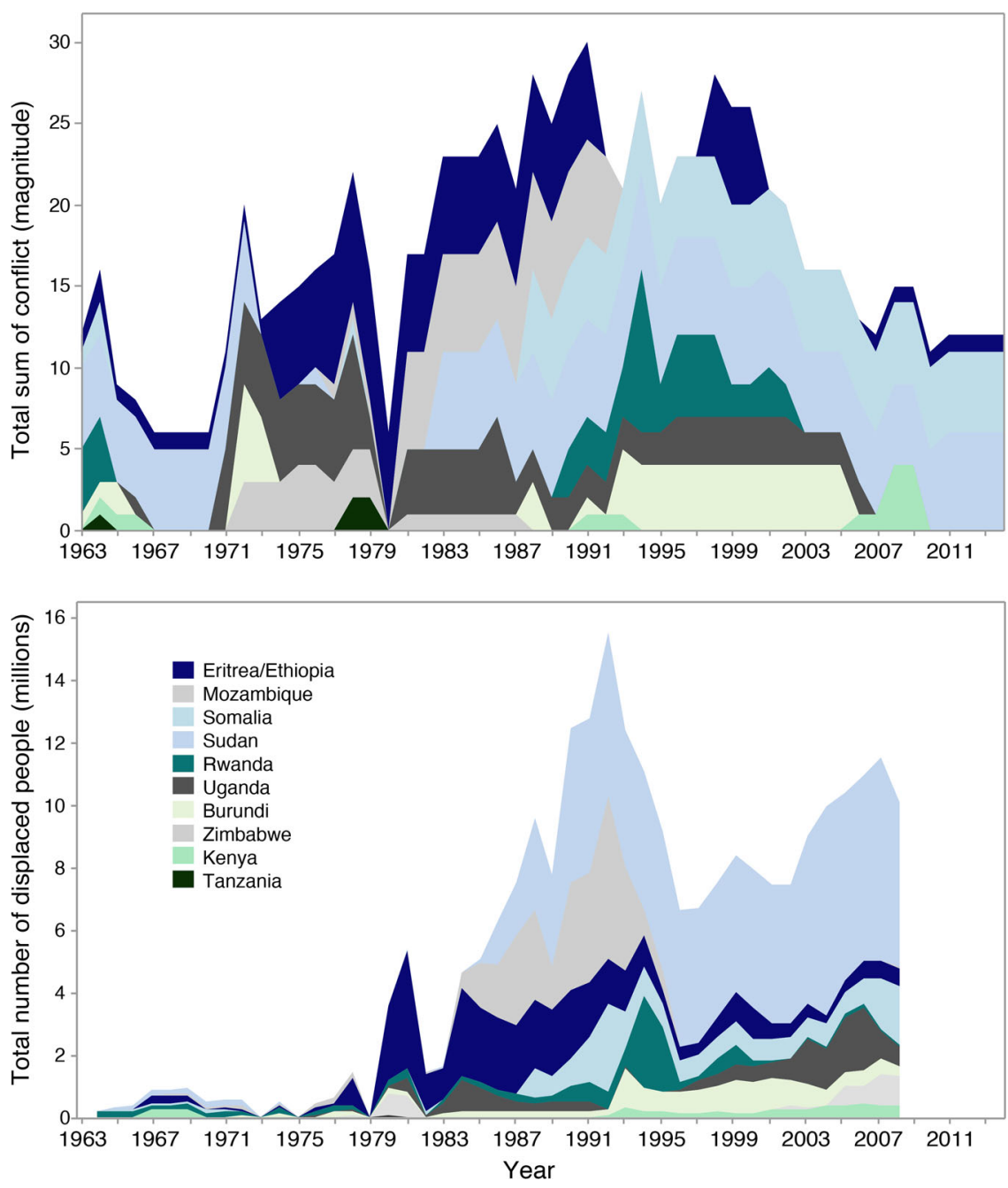

Fig. 3 Conflict and displaced people data from East Africa broken down by country since 1963

1963 and 2014. (3) Economic development as studies suggest that there could be a negative relationship with conflict (Hegre and Sambanis, 2006). (4) Rate of economic growth (annual rate of change in GDP in \%) as it has been associated with conflict. Economic data used is GDP per capita in US Dollars from between 1970 and 2014 and is derived from the United Nation Statistic Division (UNSD, 2016). (5) Political regime is included as there is evidence that highly democratic countries are associated with a decrease in conflict (Muller and Weede, 1990; Hegre, 2001). Data is taken from a database (Marshal et al., 2016a) on the political regime characteristics of each country constructed as part of the Polity IV Project from the Centre for Systemic Peace with the unit of analysis being the index Polity2 which is a scale of political regimes from +10 (strongly democratic) to -10 (strongly autocratic) updated in 2016 (Marshall et al., 2016b). (6) Life expectancy is included as an index for development and data is taken from The World Bank database (The World Bank Group, 2017, https://data.worldbank.org/).

\section{Results}

The overall level of conflict for all 10 East African countries recorded in the MEPV Database from 1963-2014, follows an inverted ' $U$ ' trend (Figs. 2 and 3). Following the initial decade of relatively low conflict across the region, conflict gradual increases in 1981 to reach a maximum peak in 1991. This peak is followed by an overall gradual decrease until 2014. At its peak in 1991, conflict occurs in 8 out of 10 countries and decreases in all post1991. Total sum of displaced people (TDP) is low and stable from 1964-1979, fluctuating between 160,000 and 940,000 (Figs. 2 and 3). This increases sharply in 1980 and 1984, coinciding well with an increase in total conflict before reaching maximum peak in 1992 at 15.5 million people. A decrease occurs after 1992, which coincides with a decrease in total conflict. In 1996, TDP increases and this coincides with an increase in interstate conflict. Interestingly, whereas conflict decreases after its peak in 1991, TDP continues to rise until 2008.

There is a long-term trend in the PDSI between 1963-2014 (Fig. 4) to drier conditions. Peak drought (minimum PDSI) coincides with maximum TDP in 1992. During the same period population increased continuously from 84.5 million to nearly 360 million (UNPD, 2017) (Fig. 4). Population growth follows an inverse 'U' trend by increasing rapidly from 1963-1983, a decade before maximum conflict and TDP, then declining from 1983 to 2014. Economic development crudely measured by GDP per capita increases from 1970-2014 from a minimum of $\$ 185$ in 1985 to $\$ 1054$ by 2014 (UNSD, 2016). Economic growth follows an overall ' $U$ ' shaped trend with negative growth for years 1981-1985, 1987, 1989-1994, 1998-2001, with peak minimum negative growth rate of $-7.49 \%$ in 1992 coinciding with peak in TDP and a year prior to the peak in conflict. Political stability follows a ' $U$ ' shaped trend, decreasing from -3 in 1963 to a 

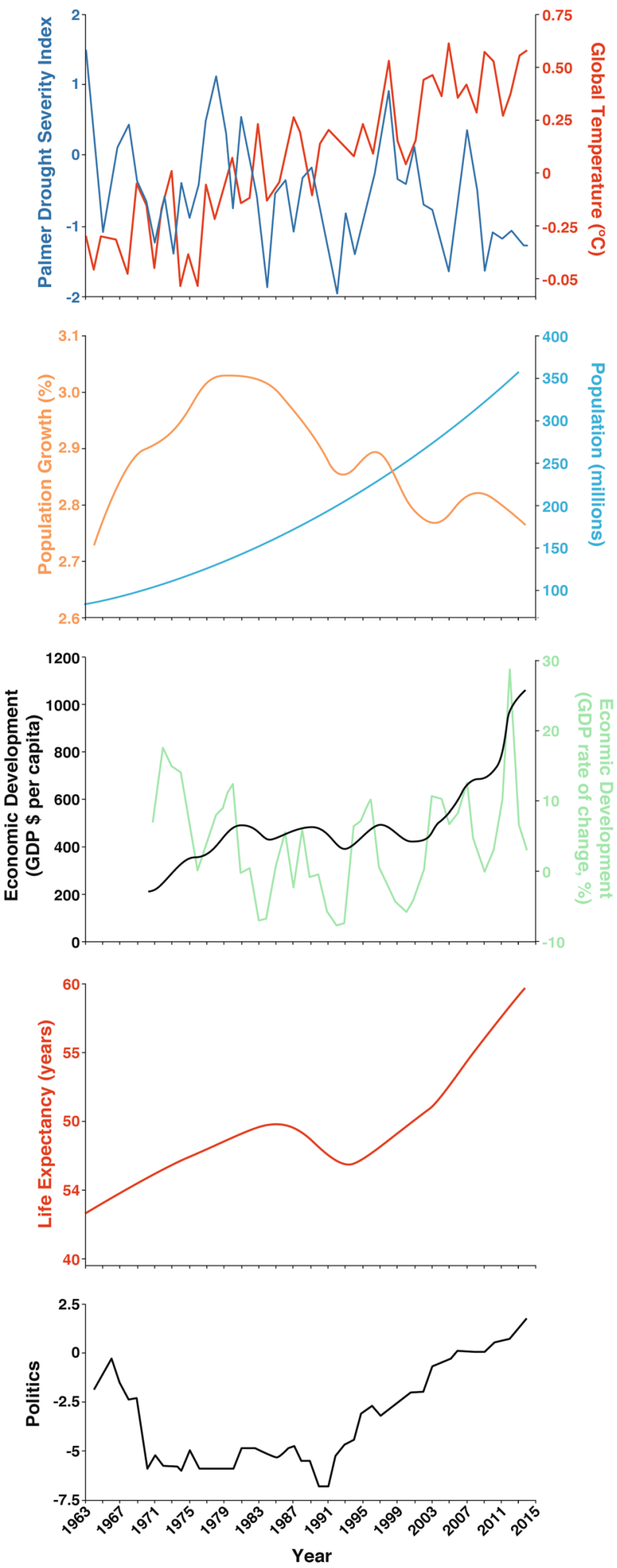

Fig. 4 Comparison of global temperatures and the Palmer Drought Index, with combined data for the 10 studied East African countries for population size, population growth, GDP per capital, rate of change of GDP per capita, life expectancy and political stability

minimum of -7 in 1989 before gradually increasing to an average of 2 in 2014. Life expectancy increases throughout the period from a minimum of 43 years in 1963 to 60 years in 2014, with a slight decrease from 1986 to 1993, which coincides with maximum conflict and maximum TDP.
The potential influences (independent variables) on conflict, TDP and refugees (dependent variables) were statistically explored both for the whole of East Africa and for each country individually. All independent variables were lagged by 1, 2, 3, 5 and 10 years to account for lag between change in independent variable and the effect on the dependent variable and statistically tested. Regression analysis was used to study the relationship between individual independent variables and conflict, TDP and refugees. Optimisation regression modelling was also used to explore which combination of independent variables best model the dependent variables. Optimisation modelling uses a stepwise regression to optimise the response variable by adding or removing independent variables based on their statistical significance (further explanation in Freedman, 2009). A predicted $r^{2}$ value was generated to represent the $\%$ of the variation in the dependent variable explained by the regression model. This approach avoids the problem with regular $r^{2}$ values that can increase every time you add a predictor which may lead to misleading, false or overly complex models. Though the optimal solution might be mathematically sound, it may not necessarily be theoretically sound, therefore, the outputs from the modelling are compared with the direct observation of the data and our theoretical knowledge about cause and effect in human societies.

Regression analysis for the East African regional collated data found there was no significant relationship between total conflict and PDSI ( $p=0.887$, Table 1$)$. The relationship between conflict and population growth was found to be statistically significantly positive for lag1-10 ( $\left.p=0.000-0.014, r^{2}=12-42.2 \%\right)$. Economic growth and conflict was found to be statistically significantly negative for the same year $\left(p=0.000, r^{2}=30\right)$ and lag1-2 $(p=$ $\left.0.000, r^{2}=22-33.3 \%\right)$. Political stability with all lags was found to have a statistically significant negative relationship $(p=$ $\left.0.000-0.016, r^{2}=11.1-46 \%\right)$ suggesting that poor government can have a decadal effect on a society. The statistical tests were also carried out for all the independent variables against societal conflict which produced the same results to those found for total conflict. Table 2

A statistically significantly negative relationship was found between PDSI and TDP in the same year $\left(p=0.040, r^{2}=9.5\right)$ and with lag1 $\left(p=0.017, r^{2}=12.6\right.$, Table 3$)$. Population growth was found to be statistically significant for the same year, lag1 and lag10 ( $\left.p=0.000, r^{2}=34 \%\right)$ however, only the lag10 was found to be theoretically sound, and likewise for politics for the same year $\left(p=0.039, r^{2}=9.5\right)$. Economic growth was found to be negatively statistically significant for the same year and lags $1-10(p=$ $\left.0.001-0.032, r^{2}=12.1-28.1 \%\right)$. Statistical analysis for total refugees generated similar results with statistically significant relationship found against PDSI in the same year $\left(p=0.022, r^{2}=\right.$ $11.6 \%)$ and lag1 $\left(p=0.10, r^{2}=14.6\right)$, population growth lag5 and lag10, economic growth for the same year and all lags, and politics lag2-10. Similarly, statistically significant relationships found for the data on IDP were PDSI lag1 $(p=0.030,10.5 \%)$, population growth lag10, economic growth lag1-10 and political state in the same year. Upon further statistical tests for each country individually, the relationship between PDSI and TDP was found to be statistically significant for 6 out of 10 countries.

\section{Discussion}

The optimisation modelling (Table 3 ) suggests that about $80 \%$ of total conflict throughout this period can be explained by population growth lagged by 10 years, political stability lagged by 3 years and economic growth within the same year. Societal conflict produced similar results at nearly $85 \%$. Climatic changes represented by PDSI and the global temperature curve were not statistically significant. These results are borne out by a visual 
Table 1 Results for the regression tests for total conflict and all independent variables $p$-values (95\% significance shaded) and $r^{2}$-values (in brackets)

\begin{tabular}{lllllll} 
Lags in years & $\mathbf{0}$ & $\mathbf{+ 1}$ & $\mathbf{+}$ & $\mathbf{+ 3}$ & $\mathbf{+ 5}$ \\
\hline Palmer Drought Severity Index & $0.887(0.0)$ & $0.742(0.2)$ & $0.269(2.5)$ & $0.186(3.7)$ & $0.286(2.5)$ & $0.988(0.0)$ \\
Population & $0.350(1.5)$ & $0.468(1.1)$ & $0.493(1.0)$ & $0.653(0.4)$ & $0.845(0.1)$ & $0.047(9.5)$ \\
Population growth & $0.123(4.8)$ & $0.014(12.0)$ & $0.002(19.2)$ & $0.000(26.6)$ & $0.000(38.0)$ & $0.000(42.2)$ \\
Economic development & $0.072(7.3)$ & $0.065(7.9)$ & $0.112(6.0)$ & $0.381(1.9)$ & $0.375(2.1)$ & $0.288(3.4)$ \\
Economic growth & $0.000(30.0)$ & $0.000(33.3)$ & $0.002(22.0)$ & $0.059(8.8)$ & $0.124(6.3)$ & $0.706(0.5)$ \\
Political state & $0.016(11.1)$ & $0.002(17.5)$ & $0.000(22.7)$ & $0.000(26.4)$ & $0.000(33.8)$ & $0.000(47.0)$ \\
Life expectancy & $0.679(0.3)$ & $0.770(0.2)$ & $0.752(0.2)$ & $0.832(0.1)$ & $0.759(0.2)$ & $0.137(3.3)$ \\
Global temperature & $0.129(4.6)$ & $0.163(3.9)$ & $0.141(4.5)$ & $0.154(4.3)$ & $0.533(0.9)$ & $0.110(6.3)$
\end{tabular}

Table 2 Results for regression tests for total displaced people and all independent variables $p$-values (95\% significance shaded) and $r^{2}$-values (in brackets)

\begin{tabular}{lllllll} 
& $\mathbf{0}$ & $\mathbf{+ 1}$ & $\mathbf{+}$ & $\mathbf{+ 3}$ & $+\mathbf{5}$ & $+\mathbf{1 0}$ \\
\hline Palmer Drought Severity Index & $0.040(9.5)$ & $0.017(12.6)$ & $0.051(8.8)$ & $0.100(6.4)$ & $0.189(4.4)$ & $0.594(0.8)$ \\
Population & $0.000(65.2)$ & $0.000(65.2)$ & $0.000(64.0)$ & $0.000(62.8)$ & $0.000(60.1)$ & $0.000(50.3)$ \\
Population growth & $0.012(13.9)$ & $0.038(9.9)$ & $0.126(5.6)$ & $0.346(2.2)$ & $0.699(0.4)$ & $0.000(34.0)$ \\
Economic development & $0.000(34.8)$ & $0.000(38.4)$ & $0.000(44.4)$ & $0.000(47.9)$ & $0.000(52.1)$ & $0.000(59.8)$ \\
Economic growth & $0.032(12.1)$ & $0.018(14.9)$ & $0.015(16.2)$ & $0.006(20.5)$ & $0.001(28.1)$ & $0.017(20.1)$ \\
Political state & $0.039(9.5)$ & $0.184(4.1)$ & $0.411(1.6)$ & $0.644(0.5)$ & $0.968(0)$ & $0.063(9.8)$ \\
Life expectancy & $0.000(28.5)$ & $0.000(34.2)$ & $0.000(40.4)$ & $0.000(47.6)$ & $0.000(64.2)$ & $0.000(66.5)$ \\
Global temperature & $0.000(54.4)$ & $0.000(59.6)$ & $0.000(54.3)$ & $0.000(51.2)$ & $0.000(48.9)$ & $0.001(27.1)$ \\
& & & & &
\end{tabular}

Table 3 Summary of the best combinations generated from extensive optimisation modelling to best explain the five dependent variables

\begin{tabular}{llll} 
& Input variables & Significant variables & \% explained by the model \\
\hline Total conflict & $P G(10)+E G+P S(3)$ & $P G(10)+E G+P S(3)$ & 80.27 \\
Societal conflict & $P G(10)+E G(1)+P S(3)$ & $P G(10)+E G(1)+P S(3)$ & 83.79 \\
Total displaced people & $P D S I+P G(10)+E G(10)$ & $P G(10)+E G(10)$ & 68.53 \\
Refugees & $P D S I(1)+P G(10)+E G(1)+P S(2)$ & $P D S I(1)+P G(10)+E G(1)+P S(2)$ & 88.69 \\
Internal displaced people & $P D S I(1)+P G(10)+E G(10)$ & $P G(10)+E G(10)$ & 63.20 \\
\hline (number) represents years the variable was lagged & & \\
PDSI Palmer Drought Severity Index, PG population growth, EG economic growth, PS political stability & \\
\hline
\end{tabular}

inspection of the data, as the population growth, political stability and economic growth data all have a U-shape over the period of time in question as do the total and societal conflict data. Whereas the PDSI and global temperature data have a long-term trend with a decadal variation, neither of which is observed in the conflict data. What is of interest is the lag in the socio-political data that seems to have the most predictive ability for the conflict data. Population growth lagged by 10 years implies that it is not the initial expansion of the population that stresses society but the consequences of the population expansion which is felt a decade later as children survive to adulthood and people live longer. Political stability lagged by 3 years suggest that the effects of unstable and ineffective governmental regimes may take a few years until the regional economy and society reaches a critical point which gives rise to significant violent eruptions. This is also supported by the fact that poor economic growth lags political instability but there is no lag between economic growth and total conflict.

For TDP, optimisation modelling suggests that nearly $70 \%$ can be predicted by population growth and economic growth when both are lagged by 10 years. Despite PDSI being statistically significant in the regression analysis, in the optimisation modelling PDSI's contribution was not significant. Similar results were found for IDP. These results are borne out by a visual inspection of the data as the population growth, economic growth data and TDP data all have a U-shape over the period of time in question Whereas the PDSI and global temperature data have a long-term trend with a decadal variation, neither of which is observed in the TDP or the IDP data. What is interesting to note is that political stability is not significant in the optimisation modelling, despite the fact that the peak of TDP and the worst period for political stability coincide around 1991. Following this trough, there is a rapid rise in political stability which coincides with a large drop in TDP and this may suggest that there is a nonlinear relationship between political stability and TDP. We speculate that when political systems are extremely unstable, improvement in governmental regimes may have an indirect and disproportionate effect on forced movement of people within and between countries. As for refugees, over $90 \%$ can be explained by PDSI lagged by 1 year was significant, population growth lagged by 10 years, economic growth lagged by a year and political stability lagged by 2 years. A visual inspection of the data shows that the increase in refugees in the 1980s seem to coincide with a period of major droughts across East Africa while the subsequent 
decrease in the 1990s coincides with a shift to much wetter conditions shown by the PDSI. This suggests that significant climatic changes deviating away from the average to both drier or wetter conditions may directly and / or indirectly affect people significantly enough to drive them away from their homes and to cross international boundaries.

\section{Conclusion}

This study discusses and exposes the complexity of the climateconflict nexus. The evidence from East Africa is that no single factor can fully explain conflict and the displacement of people. Instead, long-term population growth, short-term negative economic growth and extreme political instability seem to be primarily linked to conflict. This is in agreement with Buhaug et al., (2015) who suggested socio-political factors were more important than climate change. The displacement of people, particularly across international boundaries as refugees, in this region is also shown to be in part driven and exacerbated by intense droughts which can be in part linked to the long-term drying trend that has been ascribed to climate change (Hartmann et al., 2013). The question arises, however, whether drought would have exacerbated the displacement of people across international boundaries had there been slower expansion of the population, positive and rapid economic growth and more stable political regimes in the region. Hence, this study may not be a definitive test of the climate-conflict nexus as simultaneous peaks in both conflict and displaced people in the 1980s and 1990s across East Africa suggest a geopolitical and social narrative. Nonetheless, we note that while conflict has continued to decrease across the entire region following the end of the Cold War, the number of displaced people remains high. This study demonstrates that within socially and geo-politically fragile systems, climate change may potentially exacerbate the situation particularly with regards to enforced migration.

Received: 15 September 2017 Accepted: 13 March 2018

Published online: 24 April 2018

\section{References}

Adano WR, Dietz T, Witsenburg K, Zaal F (2012) Climate change, violent conflict and local institutions in Kenya's drylands. J Peace Res 49:65-80

Adger WN, Pulhin JM, Barnett J, Dabelko GD, Hovelsrud GK, Levy M, Oswald US, Vogel CH (2014) Human security. In: Field CB, Barros VR, Dokken DJ, Mach KJ, Mastrandrea MD, Bilir TE, Chatterjee M, Ebi KL, Estrada YO, Genova RC, Girma B, Kissel ES, Levy AN, MacCracken S, Mastrandrea PR, White LL (eds) Climate change 2014: impacts, adaptation, and vulnerability. Part A: global and sectoral aspects. Contribution of working group II to the fifth assessment report of the Intergovernmental Panel on Climate Change. Cambridge University Press, Cambridge, UK and New York, NY, p 755-791

Alley WM (1984) The Palmer drought severity index: limitations and assumptions. J Clim Appl Meteorol 23:1100-1109

Barnett J, Adger NW (2007) Climate change, human security and violent conflict. Polit Geogr 26:639-655

Barrios S, Bertinelli L, Strobl E (2010) Trends in rainfall and economic growth in Africa: a neglected cause of the African growth tragedy. Rev Econ Stat 92:350-366

Bernauer T, Böhmelt T, Koubi V (2012) Environmental changes and violent conflict. Environ Res Lett 7:15601. (8pp)

Blattman C, Miguel E (2010) Civil war. J Econ Lit 48:3-57

Boko M, Niang I, Nyong A, Vogel C, Githeko A, Medany M, Osman-Elasha B, Tabo R, Yanda P (2007) Africa. In: Parry ML, Canziani OF, Palutikof JP, van der Linden PJ, Hanson CE (eds) Climate change 2007: impacts, adaptation and vulnerability. Contribution of working group II to the fourth assessment report of the Intergovernmental Panel on Climate Change. Cambridge University Press, Cambridge, UK, p 433-467

Buhaug H (2015) Climate-conflict research: some reflections on the way forward. Wiley Interdiscip Rev Clim Change 6:269-275
Buhaug H, Nordkvelle J, Bernauer T, Böhmelt T, Brzoska M, Busby JW, Ciccone A, Fjelde H, Gartzke E, Gleditsch NP, Goldstone JA (2014) One effect to rule them all? A comment on climate and conflict. Clim Change 127:391-397

Buhaug H, Benjaminsen TA, Sjaastad E, Theisen OM (2015) Climate variability, food production shocks, and violent conflict in sub-saharan Africa. Environ Res Lett 10:125015

Burke M, Miguel E, Satyanath S, Dykema J, Lobell D (2009) Warming increases the risk of civil war in Africa. Proc Natl Acad Sci 106:20670-20674

Burrows K, Kinney PL (2016) Exploring the climate change, migration and conflict nexus. Int J Environ Res Public Health 13:443

Climate Refugee (2010) MP Nash (director), LA Think Tank, USA. http://www. climaterefugees.com/home.html

Collier P, Hoeffler A (2004) Greed and grievance in civil war. Oxf Econ Pap 56:563-595

Cong L, LI XH, Zhang F, Cao YL (2017) A study on drought temporal-variation characteristic of Chao Yang district in 1952-2015 based on PDSI. Water Sav Irrig 3:16

Dai A, Trenberth KE, Qian T (2004) A global data set of Palmer Drought Severity Index for 1870-2002: relationship with soil moisture and effects of surface warming. J Hydrometeorol 5:1117-1130

De Châtel F (2014) The role of drought and climate change in the Syrian uprising: untangling the triggers of the revolution. Middle East Stud 50:521-535

Detges A (2016) Local conditions of drought-related violence in sub-saharan Africa the role of road and water infrastructures. J Peace Res 53:696-710

Dixon J (2009) What causes civil wars? Integrating quantitative research findings. Int Stud Rev 11:707-735

Eck K (2012) In data we trust? A comparison of UCDP GED and ACLED conflict events datasets. Coop Confl 47:124-141

Fearon JD, Laitin DD (2003) Ethnicity, insurgency, and civil war. Am Political Sci Rev 97:75-90

Field CB et al. (2014) Summary for policymakers. Climate change 2014: impacts, adaptation, and vulnerability. Part A: global and sectoral aspects. contribution of working group II to the fifth assessment report of the Intergovernmental Panel on Climate Change. Cambridge University Press, Cambridge, UK and New York, NY, USA, pp 1-32. https://www.tandfonline.com/doi/abs/ 10.1080/13698249.2014.979019

Fisk K (2015) Refugee geography and the diffusion of armed conflict in Africa. Civil Wars 16:255-275

Fjelde H, von Uexkull N (2012) Climate triggers: rainfall anomalies, vulnerability and communal conflict in sub-saharan Africa. Polit Geogr 31:444-453

Freedman DA (2009) Statistical models: theory and practice. Cambridge University Press, Cambridge

Gleditsch NP, Hegre H, Strand H (2009) Democracy and civil war. Handbook of war studies III: the intrastate dimension. 155-192

Gleditsch NP (2012) Whither the weather? Climate change and conflict. J Peace Res 49:3-9

Gleick PH (2014) Water, drought, climate change, and conflict in Syria. Weather Clim Soc 6:331-340

Hartmann DL, Klein Tank AMG, Rusticucci M, Alexander LV, Brönnimann S, Charabi Y, Dentener FJ, Dlugokencky EJ, Easterling DR, Kaplan A, Soden BJ, Thorne PW, Wild M, Zhai PM (2013) Observations: atmosphere and surface. In: Stocker TF et al. (eds) Climate change 2013: the physical science basis. Contribution of working group I to the fifth assessment report of the Intergovernmental Panel on Climate Change. Cambridge University Press, Cambridge, United Kingdom and New York, NY, USA

Hauge W, Ellingsen T (2001) Causal pathways to peace. In: Diehl P, Gleditsch N (eds) Environmental conflict. Westview Press, Boulder USA

Hegre H (2001) Toward a democratic civil peace? Democracy, political change, and civil war, 1816-1992. Am Political Sci Assoc 95:33-48

Hegre H, Sambanis N (2006) Sensitivity analysis of empirical results on civil war onset. J Confl Resolut 50:508-535

Heim RR (2017) A Comparison of the early twenty-first century drought in the United States to the 1930s and 1950s drought episodes. Bull Am Meteorol Soc 98:2579-2592

Hendrix CS, Glaser SM (2007) Trends and triggers: climate, climate change and civil conflict in Sub-Saharan Africa. Polit Geogr 26:695-715

Hendrix CS, Salehyan I (2012) Climate change, rainfall, and social conflict in Africa. J Peace Res 49:35-50

Homer-Dixon TF (1999) Environmental scarcities and violent conflict: Evidence from cases. Int Secur 19:5-40

Hsiang SM, Burke M (2014) Climate, conflict, and social stability: what does the evidence say? Clim Change 123:39-55

Ide T, Schilling J, Link JSA, Scheffran J, Ngaruiya G, Weinzierl T (2014) On exposure, vulnerability and violence: spatial distribution of risk factors for climate change and violent conflict across Kenya and Uganda. Polit Geogr 43:68-81

Iyigun M, Nunn N and Qian N (2017) Winter is coming: the long-run effects of climate change on conflict, 1400-1900. National Bureau of Economic Research No. w23033, Washington DC 
Johnson DH (2003) The root causes of Sudan's civil wars. Indiana University Press, Bloomington, USA

Ki Moon B (2007) A climate culprit in Darfur. Washington Post, June 16 June, p. A15

KNMI (2016) Climate Explorer. https://climexp.knmi.nl/start.cgi. Accessed 18 May 2016

Lecoutere E, D'Exelle B and Van Campenhout B (2010) Who engages in water scarcity conflicts? A field experiment with irrigators in semi-arid Africa. MICROCON Research Working Paper No. 31, Brighton, UK

Marshall MG (2016a) Dataset: major episodes of political violence, 1946-2015. Integrated Network for Societal Conflict Research (INSCR). Data Page, Center for Systemic Peace. http://www.systemicpeace.org/inscrdata.html. Accessed 17 May 2016

Marshall MG (2016b) Codebook: major episodes of political violence (MEPV2015). Integrated Network for Societal Conflict Research (INSCR). Data Page, Center for Systemic Peace. http://www.systemicpeace.org/. Accessed 17 May 2016

Marshall MG (2016c) War list: major/ episodes of political violence, 1946-2015. Integrated Network for Societal Conflict Research (INSCR). Data Page, Center for Systemic Peace. http://www.systemicpeace.org/warlist/warlist.htm. Accessed 17 May 2016

Marshall MG (2016d) Forcibly displaced populations, 1964-2008. Integrated Network for Societal Conflict Research (INSCR). Data Page, Center for Systemic Peace. http://www.systemicpeace.org/inscrdata.html. Accessed 17 May 2016

Marshal MG, Gurr TR, Jaggers K (2016a) Dataset users' manual: Polity IV Project. Integrated Network for Societal Conflict Research (INSCR). Data Page, Center for Systemic Peace. http://www.systemicpeace.org/inscr/ p4manualv2015.pdf. Accessed 18 May 2016

Marshall MG, Gurr TR, Jaggers K (2016b) Dataset: regime authority characteristics and transitions datasets. Integrated Network for Societal Conflict Research (INSCR). Data Page, Center for Systemic Peace. http://www.systemicpeace. org/inscrdata.html. Accessed 18 May 2016

McKee TB, Doesken NJ and Kleist J (1993) The relationship of drought frequency and duration to time scales. Proceedings of the 8th conference on applied climatology, Anaheim, CA, vol 17, p 179-183

Meier P, Bond D, Bond J (2007) Environmental influences on pastoral conflict in the Horn of Africa. Polit Geogr 26:716-735

Miguel E, Satyanath S, Sergenti E (2004) Economic shocks and civil conflict: an instrumental variables approach. J Political Econ 112:725-753

Muller EN, Weede E (1990) Cross-national variation in political violence a rational action approach. J Confl Resolut 34:624-651

NASA (2016) Goddard Institute for Space Studies (GISS). Surface temperature analysis. http://data.giss.nasa.gov/gistemp/graphs_v3/. Accessed 14 June 2016

O'Loughlin J, Witmer FD, Linke AM, Laing A, Gettelman A, Dudhia J (2012) Climate variability and conflict risk in east Africa, 1990-2009. Proc Natl Acad Sci 109:18344-18349

O'Loughlin J, Linke AM, Witmer FD (2014) Effects of temperature and precipitation variability on the risk of violence in sub-saharan Africa, 1980-2012. Proc Natl Acad Sci 111:16712-16717

Palmer WC (1965) Meteorological drought. Office of Climatology, U.S. Weather Bureau, Washington, DC

Payne RA (1995) Freedom and the environment. J Democr 6:41-55

Raleigh C, Hegre (2009) Population size, concentration, and civil war: a geographically disaggregated analysis. Polit Geogr 28:224-238

Raleigh C, Linke A, Hegre H, Karlsen J (2010) Introducing ACLED: an armed conflict location and event dataset: special data feature. J Peace Res 47:651-660

Raleigh C, Kniveton D (2012) Come rain or shine: An analysis of conflict and climate variability in East Africa. J Peace Res 49:51-64

Salehyan I, Hendrix CS, Hamner J, Case C, Linebarger C, Stull E, Williams J (2012) Social conflict in Africa: a new database. Int Interact 38:503-511

Sarkees MR, Wayman F (2010) Resort to War: 1816-2007. CQ Press, Washington DC

Schleussner CF, Donges JF, Donner RV, Schellnhuber HJ (2016) Armed-conflict risks enhanced by climate-related disasters in ethnically fractionalized countries. Proc Natl Acad Sci 113:9216-9221

Sen AK (1999) Democracy as a universal value. J Democr 10:3-17

Slettebak RT (2012) Don't blame the weather! Climate-related natural disasters and civil conflict. J Peace Res 49:163-176

Stagge JH, Tallaksen LM, Xu CY and Van Lanen HA (2014) Standardized precipitation-evapotranspiration index (SPEI): sensitivity to potential eva- potranspiration model and parameters. Proceedings of FRIEND-Water conference, Montpellier, France, p 367-373

Sundberg R, Melander E (2013) Introducing the UCDP georeferenced event dataset. J Peace Res 50:523-532

Sundberg R, Eck K, Kreutz J (2012) Introducing the UCDP non-state conflict dataset. J Peace Res 49:351-362

UNHCR (2017) Statistical year book 2016. The UN Refugee Agency. http://www. unhcr.org/uk/statistical-yearbooks.html. Accessed 9 March 2018

Urdal H (2008) Population, resources and political violence: a sub-national study of India 1956-2002. J Confl Resolut 52:590-617

UNDP (2017) United Nations, Department of Economic and Social Affairs, Population Division, World Population Prospects. http://data.un.org/Data. aspx?q=population\&d=PopDiv\&f=variableID\%3a12. Accessed 9 Mar 2018

UNSD (2016) Database: GDP by type of expenditure at current prices-National currency. http://data.un.org/Data.aspx? $\mathrm{q}=\mathrm{GDP} \& \mathrm{~d}=\mathrm{SNAAMA} \& \mathrm{f}=\mathrm{grID} \%$ 3a101\%3bcurrID\%3aNCU\%3bpcFlag\%3a0. Accessed 24 Aug 2016

USCRI-U.S. Communities for Refugees and Immigrants (2016). http://refugees. org/. Accessed 24 Aug 2016

von Uexkull N (2014) Sustained drought, vulnerability and civil conflict in subsaharan Africa. Polit Geogr 43:16-26

von Uexkull N, Croicu M, Fjelde H, Buhaug H (2016) Civil conflict sensitivity to growing-season drought. Proc Natl Acad Sci 113:12391-12396. https://doi. org/10.1073/pnas.1607542113

Vicente-Serrano SM, Beguería S, López-Moreno JI (2010) A multi-scalar drought index sensitive to global warming: the standardized precipitation evapotranspiration index-SPEI. J Clim 23:1696-1718

Wambua RM, Mutua BM, Raude JM (2017) Analysis of spatial and temporal drought variability in a tropical river basin using Palmer Drought Severity Index (PDSI). Int J Water Resour Environ Eng 9:178-190

Wischnath G, Buhaug H (2014) On climate variability and civil war in Asia. Clim Change 122:709-721

\section{Data availability}

The datasets analysed in the current study are available in the MEPV Database produced by the Centre for Systemic Peace (CSP) as part of the Integrated Network for Societal Conflict Research (INSCR), http://www.systemicpeace.org/inscrdata.html.

\section{Acknowledgements}

We would like to thank Miles Irving for designing and drawing the diagrams. We would like to acknowledge funding from the Natural Environment Research Council London DTP (NE/L002485/1) and the Royal Society.

\section{Additional information}

Competing interests: The authors declare no competing interests.

Reprints and permission information is available online at http://www.nature.com/ reprints

Publisher's note: Springer Nature remains neutral with regard to jurisdictional claims in published maps and institutional affiliations.

Open Access This article is licensed under a Creative Commons Attribution 4.0 International License, which permits use, sharing, adaptation, distribution and reproduction in any medium or format, as long as you give appropriate credit to the original author(s) and the source, provide a link to the Creative Commons license, and indicate if changes were made. The images or other third party material in this article are included in the article's Creative Commons license, unless indicated otherwise in a credit line to the material. If material is not included in the article's Creative Commons license and your intended use is not permitted by statutory regulation or exceeds the permitted use, you will need to obtain permission directly from the copyright holder. To view a copy of this license, visit http://creativecommons.org/ licenses/by/4.0/

(c) The Author(s) 2018 